REGARDS

SUR L'ECONOMIE ALLEMANDE

BULLETIN ECONOMIQUE DU CIRAC
Regards sur l'économie allemande

Bulletin économique du CIRAC

$74 \mid 2005$

Varia

\title{
Système économique allemand
}

Allemagne. Consolider le renouveau économique et social / SCHUBERT Klaus (ed), Handwörterbuch des ökonomischen Systems der Bundesrepublik Deutschland

\section{(2) OpenEdition}

12 Journals

Édition électronique

URL : http://journals.openedition.org/rea/157

DOI : $10.4000 /$ rea. 157

ISBN : 978-2-8218-0844-7

ISSN : 1965-0787

Éditeur

CIRAC

Édition imprimée

Date de publication : 1 décembre 2005

ISSN : 1156-8992

\section{Référence électronique}

"Système économique allemand », Regards sur l'économie allemande [En ligne], 74 | décembre 2005,

document 7, mis en ligne le 24 avril 2008, consulté le 21 septembre 2020. URL : http://

journals.openedition.org/rea/157 ; DOI : https://doi.org/10.4000/rea.157

Ce document a été généré automatiquement le 21 septembre 2020.

(c) CIRAC 


\section{Système économique allemand}

Allemagne. Consolider le renouveau économique et social / SCHUBERT

Klaus (ed), Handwörterbuch des ökonomischen Systems der

Bundesrepublik Deutschland

\section{RÉFÉRENCE}

Allemagne. Consolider le renouveau économique et social, Examens de l'OCDE de la réforme de la réglementation, OCDE, Paris, 2004, 226 p.

SCHUBERT Klaus (ed), Handwörterbuch des ökonomischen Systems der

Bundesrepublik Deutschland, VS Verlag für Sozialwissenschaften, Wiesbaden, 2005,

$502 \mathrm{p}$.

1 «Le cadre de gouvernance et de réglementation qui s'est développé en Allemagne comporte un certain nombre d'atouts », mais il importe désormais que le gouvernement «adapte également ses traditions réglementaires pour que les changements nécessaires puissent intervenir rapidement ». Voilà les conclusions de l'évaluation effectuée par l'OCDE des réformes structurelles engagées par le gouvernement Schröder. Pour en comprendre l'ampleur et mesurer les enjeux que cela représente, il est utile de se reporter à ce manuel (SCHUBERT) qui vise justement à rendre accessibles, dans une approche systémique, les fondements du système économique allemand et les défis auxquels le soumettent l'intégration européenne comme la globalisation. Sa publication achève une trilogie d'ouvrages de référence dont les deux premiers étaient consacrés respectivement au système politique de la RFA et aux modes de fonctionnement de la société allemande. (ib) 